\title{
Frequent Foliar Sprayings of Salicylic Acid with Elevated Concentrations Enhance Growth, Yield and Fruit Quality of Strawberry (Fragaria $x$ ananassa Duch. cv. Festival) Plants
}

\author{
S.M.S. Youssef, Nashwa A.I. Abu El-Azm, S.A. AbdElhady \\ Department of Horticulture, Faculty of Agriculture, Ain Shams University, Cairo, \\ Egypt.
}

\begin{abstract}
ALICYLIC ACID regulates several physiological and biochemical processes in plants. The previous studies on strawberry used salicylic acid with low concentrations varied from 0.5 $\mathrm{mM}$ to $2.0 \mathrm{mM}$ which was sprayed once, twice or three times. The highest concentrations of salicylic acid with the maximum times of applications gave the highest values of growth and yield parameters. To study the effect of frequent foliar sprayings of salicylic acid with elevated concentrations $(0.0,1.0,2.0,3.0,4.0,5.0,6.0$, or $7.0 \mathrm{mM})$ applied every 10 days during all the growth stages of strawberry cv. Festival plants, a field experiment was conducted during 2013/2014 and 2014/2015 seasons at the Experimental Farm of Horticulture Department, Faculty of Agriculture, Ain Shams University, Qalubia Governorate, Egypt. Compared with the watersprayed plants, salicylic acid spraying up to $5.0 \mathrm{mM}$ had positive and significant effects on the vegetative growth parameters, leaf SPAD readings, leaf relative water content, leaf membrane stability index, leaf content of macronutrients, number of fruits/plant, early and total yields/plant, and fruit soluble solids content. Salicylic acid at $4.0 \mathrm{mM}$ gave the highest significant values of the aforementioned parameters. Moreover, increasing salicylic acid concentrations significantly reduced nitrate content in the fruits. In addition, a comparative microscopic examination showed thatsalicylic acid at $4.0 \mathrm{mM}$ increased the cellthickness of both upper and lower epidermis, and the thicknesses of palisade and spongy tissues. Salicylic acid spraying at 4.0 could offer an economic, rapid, applicable, and effective way for enhancing growth, yield and fruit quality of strawberry cv. Festival.
\end{abstract}

Keywords : Strawberry, Salicylic acid, Relative water content, Membrane stability, Scanning electron microscopy, Nitrate content, Yield.

\section{Introduction}

Strawberry (Fragaria $x$ ananassa Duch.) is a small popular fruit crop of great nutritional and medicinal value (Maas et al., 1991). In the three decades, strawberry has become one of the very important horticultural vegetable crops for local fresh consumption, exportation, and food processing in Egypt. In Egypt, strawberry cultivated area was 6509 ha with a total production of 283471 tons and average yield of 43.55 tons ha-1 in 2014 (FAOSTAT, 2017). Increasing the production of strawberry with high fruit quality is considered an important aim and this aim could be achieved through the foliar applications of some agro-chemicals like salicylic acid which has widely been used to enhance the growth and productivity of many vegetable crops.

Salicylic acid is an endogenous growth regulator of phenolic nature, which is normally produced in the plants in very small quantities and regulates several physiological, and biochemical processes in the plants such as seed germination, plant growth, flower induction, nutrient uptake and transport, plant water relations, membrane permeability, stomatal conductivity, photosynthesis, and enzyme activities (Hayat et al., 2010).

In the recent years, a number of studies have 
indicated that application of exogenous salicylic acid enhanced the plant growth and productivity of strawberry plants. In this regard, Karlidag et al. (2009a) investigated the effect of foliar spraying of salicylic acid at $1.0 \mathrm{mM}$ once, twice, three, or four times on growth, chlorophyll content, some fruit-quality parameters and yield of strawberry cv. Fern. Salicylic acid at $1.0 \mathrm{mM}$ for three or four times gave the highest values of leaf chlorophyll, leaf elements, early and total yields. In another study, Metwally et al. (2013) studied the effect of foliar application of salicylic acid at 1.0 or 2.0 $\mathrm{mM}$ with different number of applications (once, twice or three times) on growth, chlorophyll and mineral content of leaves, some fruit-quality parameters and yield of strawberry cv. Sweet Charlie. Application of salicylic acid at $2.0 \mathrm{mM}$ for three times was the most effective treatment in enhancing growth, fruit quality and yield. Similarly, Kalaki et al. (2014) studied the effect of different concentrations of salicylic acid $(0$, 0.5 and $1.0 \mathrm{mM}$ ) and number of applications (1, 2 and 3 times) on strawberry (Fragaria $\times$ ananassa Duch cv. Camarosa) plants. The results showed that growth parameters, chlorophyll a, b and total contents significantly increased with increasing the salicylic acid concentration and the number of applications and the highest values were obtained with salicylic acid at $1 \mathrm{mM}$ for three times.

Based on the previous studies on strawberry, the present study was carried out to investigate the effect of salicylic acid with elevated concentrations $(0.0,1.0,2.0,3.0,4.0,5.0,6.0$, or $7.0 \mathrm{mM}$ ) applied during all the growth stages of strawberry (Fragaria $x$ ananassa Duch. cv. Festival) plants.

\section{Materials and Methods}

\section{Cultivation and experimental design}

This study was conducted to evaluate the frequent foliar sprayings of salicylic acid at different concentrations $(0.0,1.0,2.0,3.0,4.0$, $5.0,6.0$, or $7.0 \mathrm{mM}$ ) on the growth, yield and fruit quality of strawberry (Fragaria $x$ ananassa Duch. cv. Festival) plants. The study was carried out during the two successive seasons of 2013/2014 and 2014/2015 at the Experimental Farm of Horticulture Department, Faculty of Agriculture, Ain Shams University, Qalubia Governorate, Egypt. According to soil analysis results, soil texture of the experimental site was a sandy loam.
Cold-stored bare rooted strawberry transplants (Fragaria $x$ ananassa Duch. cv. Festival) with one well-developed crown of diameter $\sim 10 \mathrm{~mm}$ were planted. Festival is an important strawberry cultivar which recently planted widely in Egypt. The transplants were obtained from the Strawberry and Non-Traditional Crops Improvement Center of the Faculty of Agriculture, Ain Shams University. Strawberry transplants were set up in the field on October 1st and 7th in the first and second growing seasons, respectively. The transplants were cultivated at one side of the rows at a distance of $25 \mathrm{~cm}$ between plants and $70 \mathrm{~cm}$ between rows. The plot area consisted of five rows each of $5 \mathrm{~m}$ length.

Salicylic acid was dissolved in absolute ethanol then added drop-wise to distilled water (ethanol/water: $1 / 1000, \mathrm{v} / \mathrm{v}$ ) to make the tested concentrations $(1,2,3,4,5,6$, and $7 \mathrm{mM})$. The $\mathrm{pH}$ of all solutions was set to 6.5-7. A surfactant tween $20(0.5 \%)$ was added with the control (deionized water) and all salicylic acid solutions. The plants were sprayed during early morning using a handheld sprayer. The lower leaf surface was sprayed until wetted as well as upper surface. The volume of the spray was enough to cover completely the whole plant foliage. Foliar applications of salicylic acid at the tested concentrations were performed every 10 days during all growth stages.

The eight treatments were arranged in a completely randomized blocks design with four replicates and each experimental plot was composed of five rows of $2 \mathrm{~m}$ in length.

In both seasons, all cultural practices of cultivation (irrigation, fertilization, weeding, and pest control) were carried out uniformly in all plots as recommended by the Egyptian Ministry of Agriculture for strawberry production during growth season.

\section{Data recorded}

A random sample of ten plants from the three inner rows of each experimental plot was taken at 90 days after planting for vegetative growth data. Full expanded leaves from these plant samples were used to measure chlorophyll content, relative water content, membrane stability index, and some macronutrients.

Vegetative growth

Plant length was measured using a meter scale 
and number of leaves was counted. Average leaf area was calculated as relation between area unit and fresh weight of leaves (Koller, 1972) using the following equation :

Leaf area $=$

(Disk area x No.of disks x fresh weight of leaves)/ (Fresh weight of disks)

Leaf area index was calculated as a ratio of foliage area to soil area

The plants were removed with a shovel, to prevent damage to the root system. The excess soil attached to the roots was carefully removed. In the laboratory, the plants were washed and the vegetative growth and root fresh weights were recorded. They were dried in an oven at $70^{\circ} \mathrm{C}$ until constant weight to record the vegetative growth and root dry weights.

\section{Chlorophyll measurements}

A portable chlorophyll meter (SPAD-502, Konica Minolta Sensing, Inc., Japan) was used to measure leaf greenness of the plants. SPAD-502 chlorophyll meter can estimate total chlorophyll amounts in leaves of a variety of species with a high degree of accuracy, which is a nondestructive method (Neufeld et al., 2006). At 90 days after planting, measurements were taken at four locations on each leaf, two on each side of the midrib on the full expanded leaves of randomly selected five plants per plot (Khan et al., 2003).

\section{Leaf relative water content}

Leaf relative water content was determined according to the method developed by Barrsand Weatherley (1962). Second leaf of the plants was used for determining relative water content. Fresh weight (FW) was immediately recorded, and then leaves were immediately soaked for 4 hours in distilled water at room temperature under a constant light and saturated humidity to record turgid weight (TW). The samples were then dried for 24 hours at $80^{\circ} \mathrm{C}$ for recording dry weight (DW). Relative water content (RWC) was calculated by the following formula:

$$
\mathrm{RWC}(\%)=\frac{\mathrm{FW}-\mathrm{DW}}{\mathrm{TW}-\mathrm{DW}} \times 100
$$

\section{Leaf membrane stability index}

Leaf membrane stability index (LMSI) was determined by the method of Sairam et al. (1997). Leaf disks $(200 \mathrm{mg})$ were taken in two sets of test tubes containing $10 \mathrm{ml}$ of distilled water. One set was kept at $40^{\circ} \mathrm{C}$ in a water bath for $30 \mathrm{~min}$ and electrical conductivity (C1) was measured. The second set was incubated at $100^{\circ} \mathrm{C}$ for $15 \mathrm{~min}$ and electrical conductivity (C2) was measured. MSI was calculated according to the following formula :

$$
\operatorname{LMSI}(\%)=\frac{(1-\mathrm{C} 1)}{\mathrm{C} 2} \times 100
$$

\section{Analysis of leaf nutrients}

Leaf samples from the full expanded leaves were taken at 90 days from transplanting and ovendried at $70{ }^{\circ} \mathrm{C}$ until constant weight. Then they were ground to pass a $1 \mathrm{~mm}$ sieve and $0.1 \mathrm{~g}$ of the dry samples was taken and digested using a mixture of sulphuric acid $\left(\mathrm{H}_{2} \mathrm{SO}_{4} 98 \%\right)$ and hydrogen peroxide $\left(\mathrm{H}_{2} \mathrm{O}_{2} 30 \%\right)$ as described by Allen (1974). All the studied elements were assayed in the digest of the concerned plant samples. Total nitrogen was determined using Kjeldahl method as described by Piper (1950). Phosphorus content was spectrophotometricallymeasured according to Watanabe and Olsen (1965). Potassium, calcium, and magnesium were determined as described by Chapman and Pratt (1961).

\section{Yield components}

Marketable fruits were harvested at 2-3 day intervals during the growing season, counted, and weighed to record fruit number/plant and average fruit weight. The early yield/plant was determined as weights of all harvested fruit during the first four harvests. Marketable total yield/plant was calculated.

\section{Fruit quality}

Forty full-colouredfruits were collected randomly from each treatment in the middle of the growing season (April in both seasons) as subsamples for fruit quality. Soluble solid content (SSC) was determined using a hand refractomer. Titratable acidity was determined according to A.O.A.C. (2012). The SSC/titratable acidity ratio was calculated. Nitrate content in the fruits was determined according to Al-Moshileh et al. (2004) using the HORIBA LAQUAtwin Nitrate Meter, Spectrum Technologies, Inc., IL, USA.

\section{Leaf anatomy}

In the second growing season, eight full expanded leaves from the different treatments at 90 days after planting were used to investigate the ultrastructural variations. The specimens of strawberry 
leaves were prepared by cutting into pieces $\left(1 \mathrm{~cm}^{2}\right)$ of the terminal leaflet. Each sample was immersed overnight in $6 \%$ sodium hypochlorite, $4.12 \%$ sodium chloride and $0.15 \%$ sodium hydroxide. Thereafter, the specimens were rinsed with distilled water and left to dry at room temperature. The samples were then mounted in inner side uppermost and in vertically manner on aluminum stubs, coated with gold for 3 min. in an Emscope Sputter Coater. These samples were examined using JEOL JSMT330A Scanning Electron Microscopy at $15 \mathrm{Kv}$. The images were analyzed using the SemAfore Software (version 5.21) .

\section{Statistical analysis}

All data were subjected to an analysis of variance using the CoStat package program (version 6.303, CoHort Software, USA). The differences among the means were compared using the least significance difference (LSD) at $\mathrm{p} \leq 0.05$.

\section{Results and Discussion}

Vegetative growth parameters

Data in Fig.1 clearly showed that foliar applications of salicylic acid up to $5.0 \mathrm{mM}$ had positive effects on the vegetative growth parameters of strawberry plants (plant length, number of leaves/plant, average leaf area, leaf area index, and fresh and dry weights of roots and vegetative growth) compared with the watersprayed plants in both seasons. Salicylic acid at $4.0 \mathrm{mM}$ gave the highest and significant values of the above-mentioned parameters. However, there were no significant differences between spraying of salicylic acid at 4.0 and $3.0 \mathrm{mM}$ in plant length. On the contrary, no significant differences were detected in these growth parameters between the plants sprayed with salicylic acid at 6.0 or 7.0 $\mathrm{mM}$ and the water-sprayed plants in both growing seasons. The stimulatory effects of salicylic acid sprayings on vegetative growth parameters of strawberry were reported (Karlidag et al., 2009a and b,Jamali et al., 2011, Kazemi, 2013, Metwally et al., 2013, Qureshi et al., 2013, Kalaki et al., 2014,Ghaderi et al., 2015, Jamali et al., 2015 and Faghih et al., 2017). These stimulatory effects on vegetative growth could be attributed to the positiveeffect of salicylic acid upon the endogenous phytohormones specially the growth promoters, i.e. auxins, gibberellins and cytokinins (Mady, 2014) which promote cell division and cell enlargement (Hayat et al., 2005).

\section{SPAD readings}

Foliar application of salicylic acid at concentrations up to $5 \mathrm{mM}$ resulted in significant increases in SPAD readings compared with the water-sprayed plants in both growing seasons (Fig. 2). On the contrary, no significant differences in SPAD readings were detected between the plants sprayed with salicylic acid at 6.0 or 7.0 $\mathrm{mM}$ and the water-sprayed plants in both growing seasons. The obtained results coincide with those obtained by Kalaki et al. (2014) who found that chlorophyll a, chlorophyll b and total chlorophyll contents were significantly increased with increasing salicylic acid concentration and the number of the applications. Similar increases in chlorophyll values of strawberry leaves were obtained by foliar application of salicylic acid (Karlidag et al., 2009a,b and Tohma \& Esitken, 2011). These increments in SPAD readings may be attributed to the fact that foliar application of salicylic acid decreases chlorophyll degradation (Raskin, 1992).

\section{Leaf relative water content}

Compared with the water-sprayed plants, all the tested salicylic acid concentrations significantly increased leaf relative water content in both seasons (Fig.3). Exogenous applications of salicylic acid at 3.0 or $4.0 \mathrm{mM}$ maintained the highest and significant relative water content. The increments among other salicylic acid were not significant. The obtained results are in agreement with those obtained by Karlidag et al.(2009b) who found that the highest salicylic acid concentration used $(1.0 \mathrm{mM})$ induced increases in relative water content in strawberry leaves. Similarly, Ghaderi et al. (2015) found that salicylic acid application at $1.0 \mathrm{mM}$ increased leaf relative water content in strawberry. The stimulatory effect of salicylic acid on leaf relative water content could be attributed to the fact that salicylic acid can increase leaf diffusive resistance and lower transpiration in plants (Yildirim et al., 2008).

\section{Leaf membrane stability index}

Figure 4 revealed that all the tested salicylic acid concentrations significantly increased leaf membrane stability index as compared with the water-sprayed plants in both seasons. However, these increases were not significant between the plants sprayed with $1.0 \mathrm{mM}$ and the water-sprayed plants in the first season. Foliar applications of salicylic acid at $3.0,4.0$, or $5.0 \mathrm{mM}$ maintained the highest and significant leaf membrane stability 
index. These results are in agreement with those obtained by Hayat et al. (2010) who found that salicylic acid application significantly decreased lipid peroxidation and improve membrane stability index both in unstressed as well as stressed Vigna radiate plants.
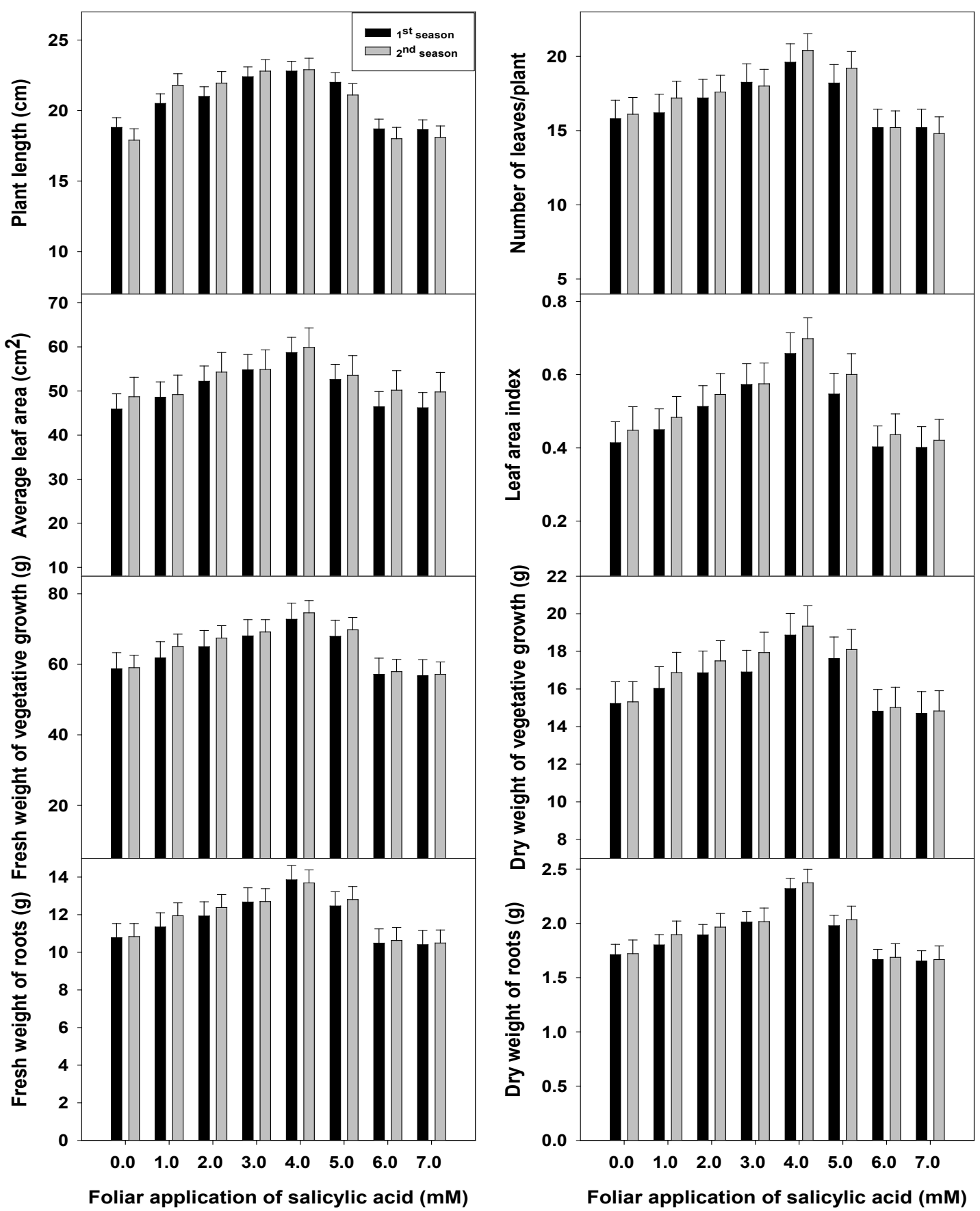

Fig. 1. Effect of foliar applications of salicylic acid concentrations on some vegetative growth parameters of strawberry (Fragaria $x$ ananassa Duch. cv. Festival) plants in 2013/2014 and 2014/2015 seasons. Vertical bars indicate the LSD value at $\mathbf{p} \leq \mathbf{0 . 0 5}$. 


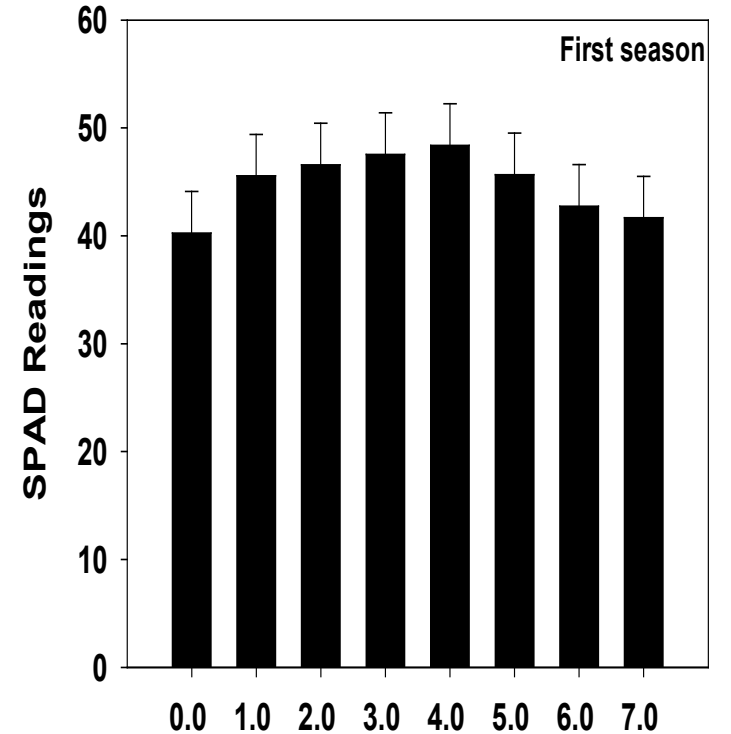

Foliar application of salicylic acid (mM)

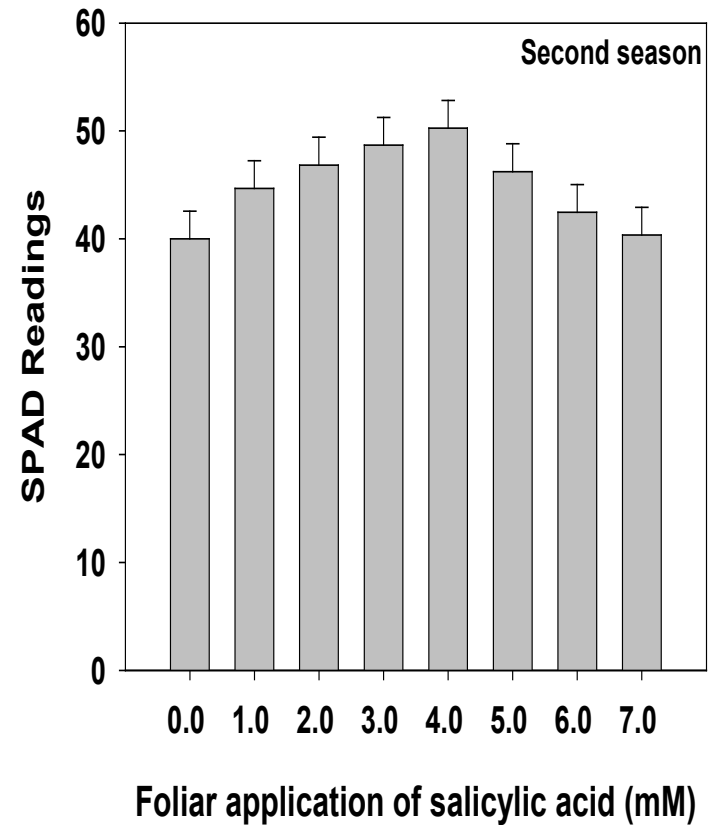

Fig. 2. Effect of foliar applications of salicylic acid concentrations on leaf SPAD readings of strawberry (Fragaria $x$ ananassa Duch. cv. Festival) plants in 2013/2014 and 2014/2015 seasons. Vertical bars indicate the LSD value at $\mathbf{p} \leq \mathbf{0 . 0 5}$.

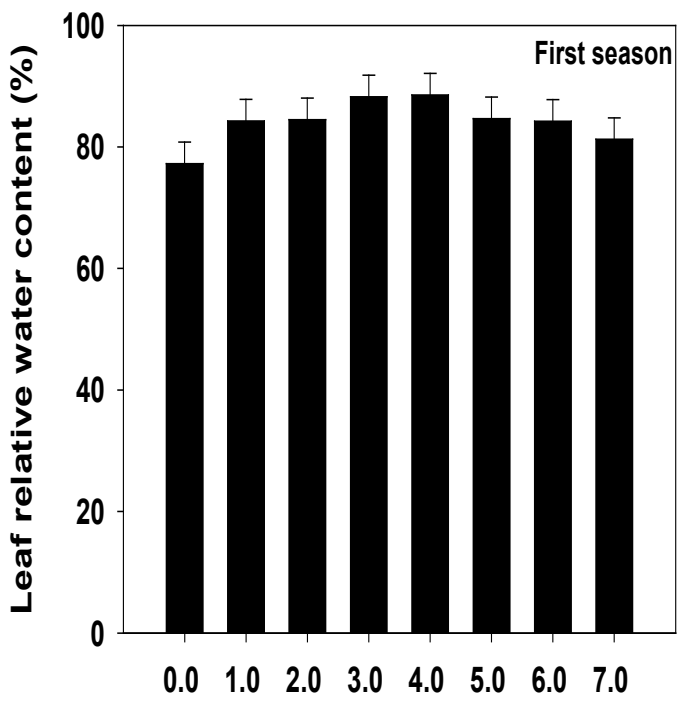

Foliar application of salicylic acid (mM)

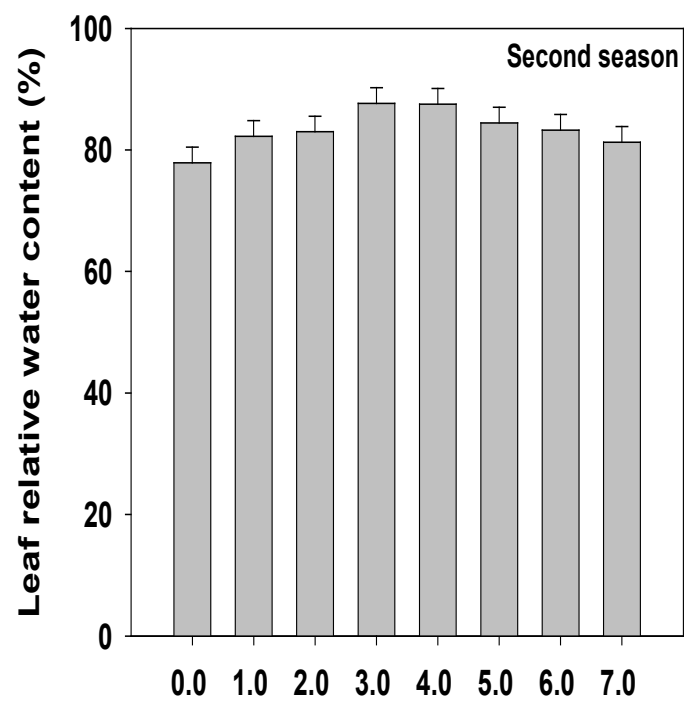

Foliar application of salicylic acid (mM)

Fig. 3. Effect of foliar applications of salicylic acid concentrations on leaf relative water content of strawberry (Fragaria $x$ ananassa Duch. cv. Festival) plants in 2013/2014 and 2014/2015 seasons.Vertical bars indicate the LSD value at $\mathbf{p} \leq \mathbf{0 . 0 5}$. 


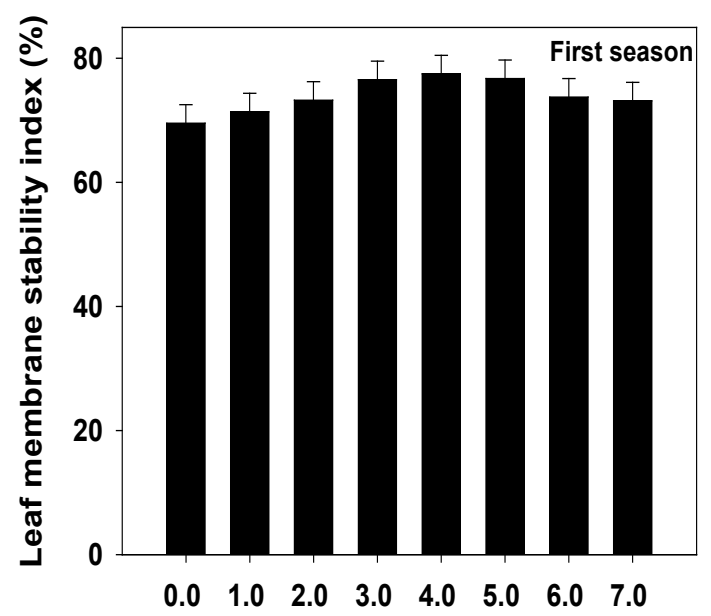

Foliar application of salicylic acid (mM)

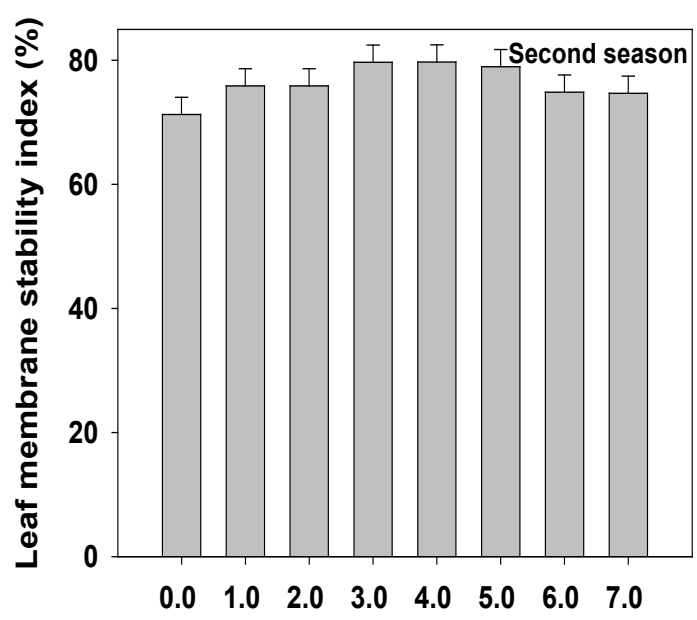

Foliar application of salicylic acid (mM)

Fig. 4. Effect of foliar applications of salicylic acid concentrations on leaf membrane stability index of strawberry (Fragaria $x$ ananassa Duch. cv. Festival) plants in 2013/2014 and 2014/2015 seasons. Vertical bars indicate the LSD value at $\mathbf{p} \leq \mathbf{0 . 0 5}$.

\section{Leaf macronutrients}

In both growing seasons, foliar applications of salicylic acid with concentrations up to 5 $\mathrm{mM}$ had positive and significant effects on the accumulation of $\mathrm{N}, \mathrm{Ca}$, and $\mathrm{Mg}$ in strawberry leaves compared with those of the water-sprayed plants, and the concentrations of 3.0 or $4.0 \mathrm{mM}$ gave the highest and significant values (Fig. 5). On the other hand, all the tested salicylic acid concentrations significantly increased $\mathrm{P}$ and $\mathrm{K}$ percent in the leaves compared the water-sprayed plants, and the concentrations of 4.0 or $5.0 \mathrm{mM}$ gave the highest and significant values. These results coincide with Karlidag et al. (2009a) who found that exogenous application of salicylic acid at the used concentration $(1.0 \mathrm{mM})$ for three or four times gave the highest values of all nutrients in the leaves of strawberry cv. Fern plants. Moreover, Jamali and Eshghi (2015) found that salicylic acid application at 0.5 or $1.0 \mathrm{mM}$ increased $\mathrm{N}, \mathrm{P}, \mathrm{K}$, $\mathrm{Ca}, \mathrm{Mg}, \mathrm{Fe}$, and $\mathrm{Zn}$ in shoot and root of strawberry cv. Selva plants. The increments in leaf content of nutrients due to salicylic acid applications are linked with the increments in plant growth parameters. In addition, the increases of $\mathrm{Ca} 2+$ in the leaves resulted from salicylic acid treatments are related with the maintenance of membrane integrity which resulted in increases in membrane stability index (Fig. 4). Moreover, the increases in $\mathrm{Mg} 2+$ are related with the increments of SPAD readings (Fig. 2), since magnesium is considered as the central atom of chlorophyll.

\section{Yield components}

Figure 6 clearly showed that all the tested concentrations of salicylic acid increased number of fruits and early marketable yield/ plant in both growing seasonssignificantly. On the other hand, spraying with the concentrations up to $5 \mathrm{mM}$ significantly increased total marketable yield/ plant compared with the water-sprayed plants. The plants sprayed with salicylic acid at $4.0 \mathrm{mM}$ produced the highest significant number of fruits, and early and total marketable yields per plant. On the contrary, salicylic acid concentrations had no effect on the average fruit weight. Earlier studies on strawberry showed that exogenous application of salicylic acid at the highest concentration and the highest number of applications resulted in the highest early and total yields of strawberry (Karlidag et al., 2009a, Metwally et al., 2013 andKalaki et al., 2014). These increases in yield components of strawberry could be a reflection of the marked increases in the vegetative growth parameters due to salicylic acid applications (Fig. 1) which gave a chance to the plant to carry more flowers and hence more fruits.

\section{Fruit quality}

In both growing seasons, all the tested 

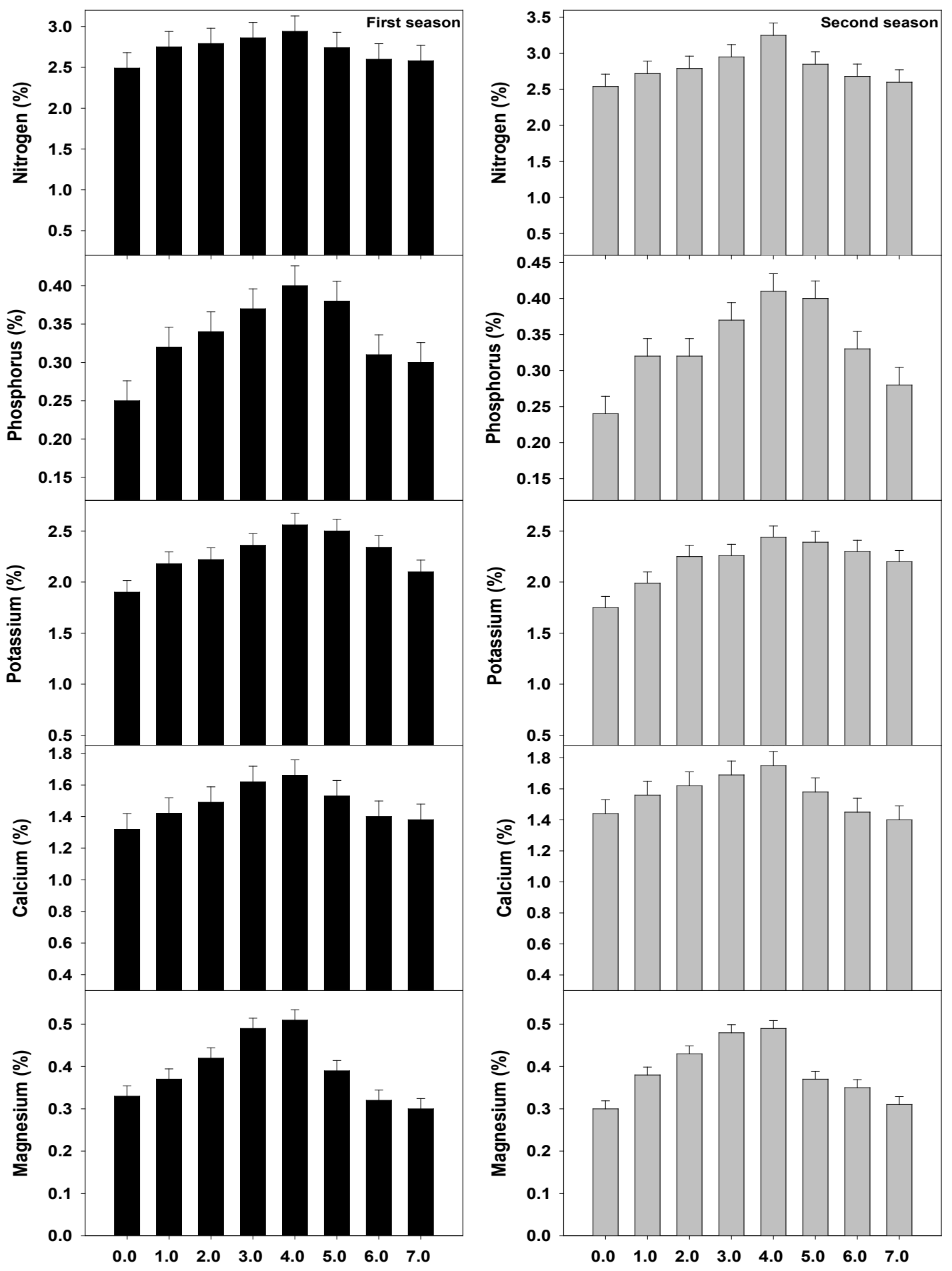

Foliar application of salicylic acid (mM)

Foliar application of salicylic acid (mM)

Fig. 5. Effect of foliar applications of salicylic acid concentrations on leaf nutrients content of strawberry (Fragariaxananassa Duch. cv. Festival) plants in 2013/2014 and 2014/2015 seasons. Vertical bars indicate the $\mathrm{LSD}$ value at $\mathbf{p} \leq \mathbf{0 . 0 5}$. 

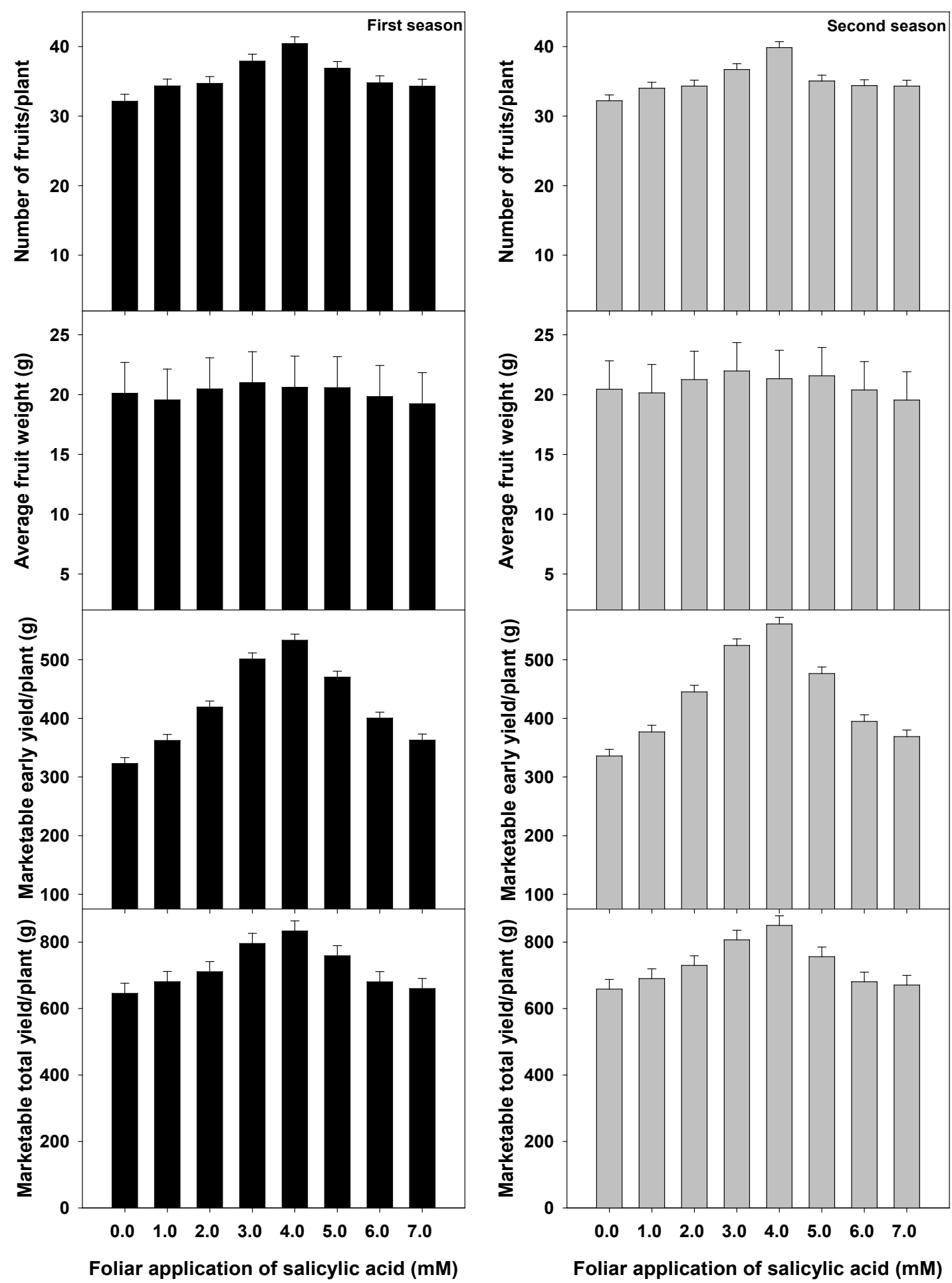

Fig. 6. Effect of foliar applications of salicylic acid concentrations on yield components of strawberry (Fragaria $x$ ananassa Duch. cv. Festival) plants in 2013/2014 and 2014/2015 seasons. Vertical bars indicate the LSD value at $\mathbf{p} \leq \mathbf{0 . 0 5}$. 
concentrations of salicylic acid increased the soluble solids content in the fruits significantly compared with those obtained from the watersprayed plants. The concentrations of 4.0 or 5.0 $\mathrm{mM}$ gave the highest and significant values
(Fig. 7). In this regard, foliar application of salicylic acid increased total soluble content in strawberry fruits (Karlidag et al., 2009a, Kazemi, 2013, Qureshi et al., 2013, Jamali et al., 2015 and Aghaeifard et al., 2016).

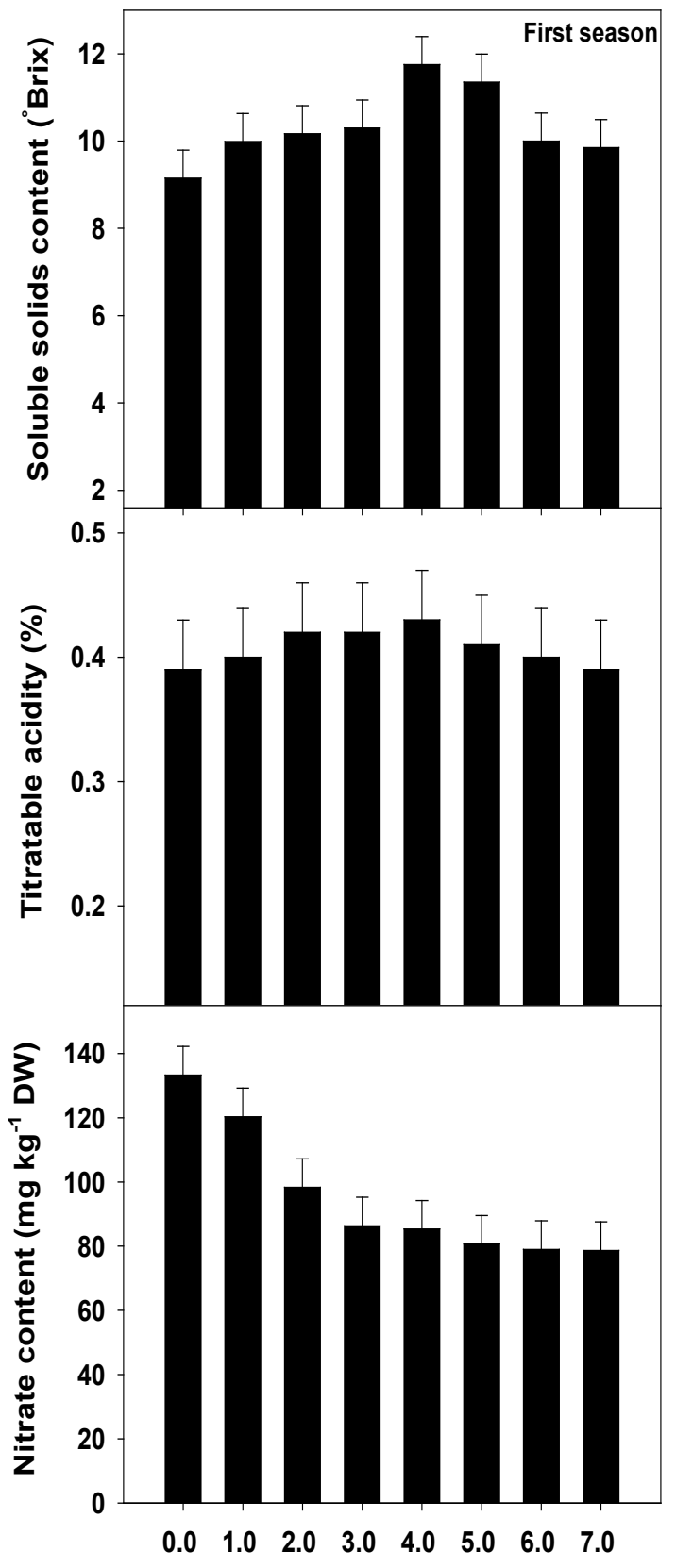

Foliar application of salicylic acid (mM)

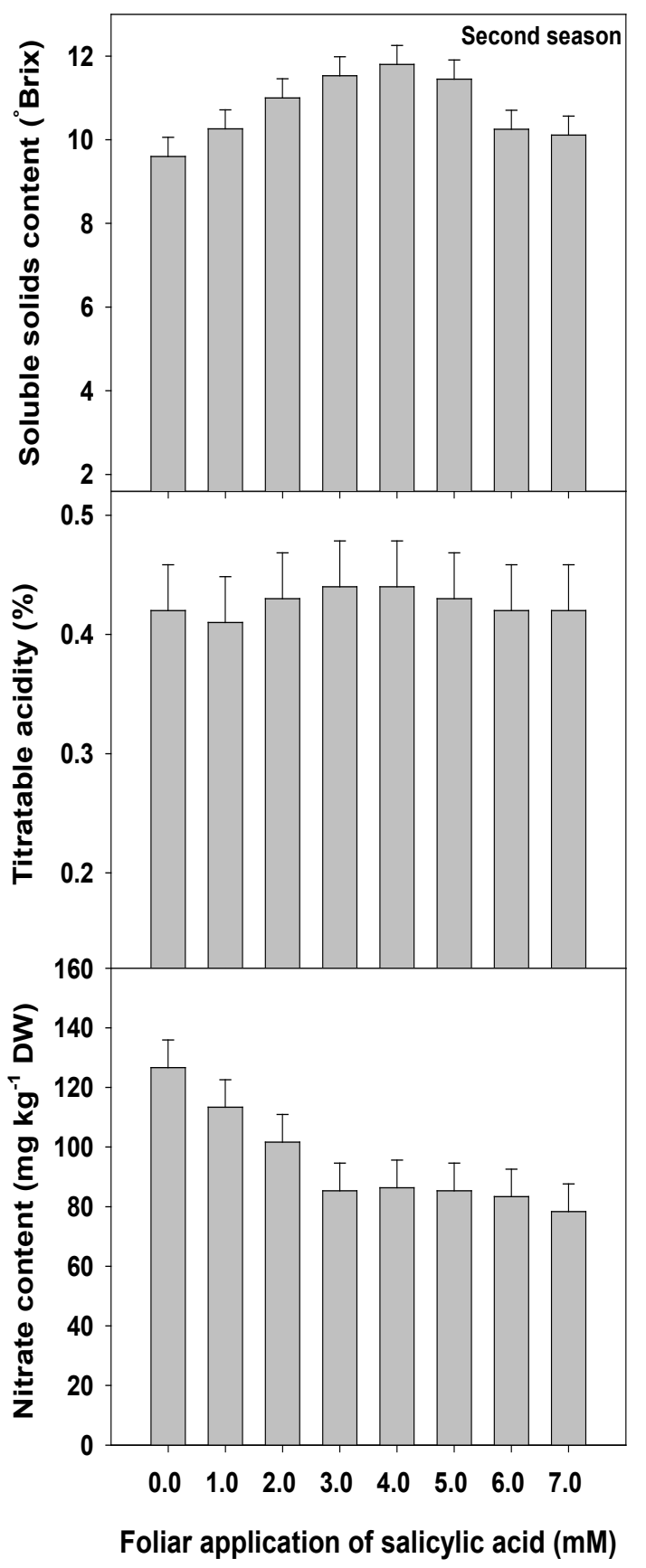

Fig. 7. Effect of foliar applications of salicylic acid concentrations on fruit quality of strawberry (Fragaria $x$ ananassa Duch. cv. Festival) plants in 2013/2014 and 2014/2015 seasons.Vertical bars indicate the LSD value at $p \leq 0.05$. 
As for the titratable acidity, no significant differences were detected among the fruits obtained from the plants sprayed with different concentrations. Similarly, salicylic acid treatments had no effect on titratable acidity of strawberry fruits in earlier studies (Karlidag et al., 2009a, Metwally et al., 2013 and Aghaeifard et al., 2016).

On the contrary, increasing salicylic acid concentrations significantly reduced the nitrate content in the fruits in both seasons. The reductions of nitrate content were not significant in the fruits of the plants sprayed with salicylic acid at 3.0, $4.0,5.0,6.0$, or $7.0 \mathrm{mM}$. These reductions in nitrate content could be attributed to the effects of salicylic acid on the activity of nitrate reductase and nitrite reductase enzymes. Nitrate reductase activity was increased with salicylic acid in mungbean (Dar et al., 2007), and cucumber (Singh el al., 2010). Also, Jain and Srivastava
(1981) found that salicylic acid increased nitrite reductase in maize. It is well known that nitrate reductase reduces nitrate $\left(\mathrm{NO}_{3}^{-}\right)$to nitrite in the cytosol (Campbell, 1988) and nitrite moves into plastids where subsequently it is reduced to $\mathrm{NH}_{4}^{+}$ by nitrite reductase enzyme.

\section{Leaf anatomy}

Based upon the obtained results, a comparative microscopic examination was performed between the leaves obtained from the control (watersprayed plants) and those obtained from plants with the most prominent response (plants sprayed with salicylic acid at $4.0 \mathrm{mM}$ ). The microscopic measurements of the transverse sections of the terminal-leaflet blade presented in Fig. 8 revealed that spraying salicylic acid at concentration of $4.0 \mathrm{mM}$ increased the thickness of the cells of both upper and lower epidermis compared with those of the water-sprayed plants. Moreover,
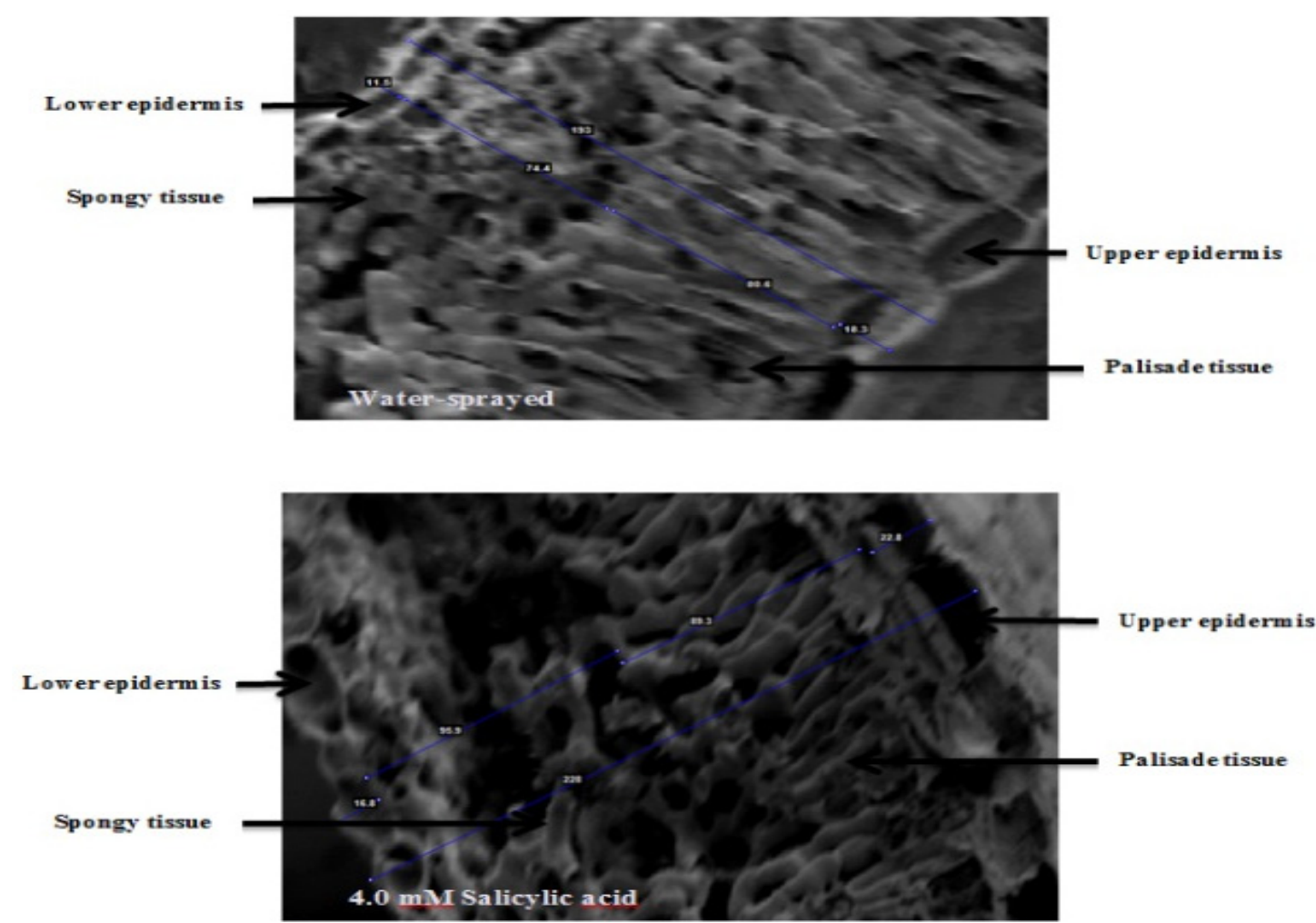

\begin{tabular}{|c|c|c|c|c|}
\hline Treatments & Upper epidermis & Palisade tissue & Spongy tissue & Lower epidermis \\
\hline Water-sprayed & $18.3 \mu \mathrm{m}$ & $80.6 \mu \mathrm{m}$ & $74.4 \mu \mathrm{m}$ & $11.5 \mu \mathrm{m}$ \\
\hline 4.0 mM Salicylic acid & $22.8 \mu \mathrm{m}$ & $89.3 \mu \mathrm{m}$ & $95.9 \mu \mathrm{m}$ & $16.8 \mu \mathrm{m}$ \\
\hline \% to water-sprayed & $\mathbf{2 4 . 5 9}$ & $\mathbf{1 0 . 7 9}$ & $\mathbf{2 8 . 9 0}$ & $\mathbf{4 6 . 0 9}$ \\
\hline
\end{tabular}

Fig. 8. Transverse sections through the blade of terminal leaflet of strawberry leaves sprayed with water or 4.0 mM salicylic acid. 
the thicknesses of palisade and spongy tissues were increased by spraying salicylic acid at 4.0 $\mathrm{mM}$ as compared to the water-sprayed plants. The obtained results are in coincidence with those of Gomaa et al. (2015) who found that foliar application of salicylic acid increased the thicknesses of palisade and spongy tissues and the thickness of lamina of Egyptian lupine. Similar results were reported on bean (Nour et al., 2012). The increases in the thickness of the cell of leaf tissues (Fig. 8) may be attributed to the cell swelling resulting from the increments of leaf relative water content (Fig. 3). Moreover, the mesophyll tissue (palisade and spongy tissues) is characterized by high concentration of chloroplast and as consequence leaf thickness increasing could be considered as a good indicator and a reliable index to photosynthetic efficiency. In this regard, microscopic data (Fig. 8) are linked with the increments in SPAD readings in the plants treated with salicylic acid (Fig. 2).

\section{Conclusion}

In conclusion, this study demonstrated that foliar spraying of salicylic acid with elevated concentrations during all growth stages induced positive effects on growth parameters, some physiological parameters, marketable fruit yield and fruit quality of strawberry cv. Festival. Spraying salicylic acid at 4.0 could offer an economic, rapid, applicable, and effective way for enhancing growth, yield and fruit quality of strawberry cv. Festival.

\section{References}

A.O.A.C. (Association of Official Analytical Chemists-International) (2012) "Official Methods of Analysis", $19^{\text {th }}$ ed., Hortwitz, W. Latimer,G.W. (Ed.), AOAC-Int. Suite 500, 481 North Frederick Avenue, Gaithersburg, Maryland, USA.

Aghaeifard, F., Babalar, M., Fallahi, E. and Ahmadi, A. (2016) Influence of humic acid and salicylic acid on yield, fruit quality, and leaf mineral elements of strawberry (Fragaria $\times$ Ananassa Duch.) cv. Camarosa. Journal of Plant Nutrition, 39 (13), 1821-1829. DOI: 10.1080/01904167.2015.1088023

Allen, S.E. (1974) "Chemical Analysis of Ecological Materials", Blackwell Scientific, Oxford, England, $565 \mathrm{p}$.

Egypt. J. Hort. Vol. 44, No.1 (2017)
Al-Moshileh, A.M., Al-Redhaiman, K.N. and ElShinawy, M.Z. (2004) The effect of nitrogen sources on yield and nitrate accumulation in lettuce and cabbage plants. Egypt. J. Appl. Sci., 19, 646-654.

Barrs, H.D. and Weatherley, P.E. (1962) A reexamination of the relative turgidity technique for estimating water deficits in leaves. Aust. J. Biol. Sci., 15 (3), 413-428. DOI: 10.1071/BI9620413

Campbell, W.H. (1988) Nitrate reduction and its role in nitrate assimilation in plants. Physiologia Plantarum, 74, 214-219. DOI: 10.1111/j.13993054.1988.tb04965.x

Chapman, H.D. and Pratt, P.F. (1961) "Methods of Analysis for Soils", Plants and Water.Univ. California, Berkeley, CA, USA.

Dar, Z., Hemantaranjan, M. and Pandey, S.K. (2007) Effects of salicylic acid on growth, nitrate reductase activity and miniral uptake by mungbean (Vigna radiata L.) under induced salinity. Legume Research, 30 (7), 133-136.

Faghih, S., Ghobadi, C. and Zarei, A. (2017) Response of strawberry plant cv. 'Camarosa' to salicylic acid and methyl jasmonate application under salt stress condition. J. Plant Growth Regul., pp 1-9. DOI 10.1007/s00344-017-9666-x

FAOSTAT (2017) Food and Agriculture organizations of the United Nations. Statistics Division. http:// www.fao.org/faostat/en/\#data/QC (accessed 12, March 2017).

Ghaderi, N., Normohammadi, S. and Javadi, T. (2015) Morpho-physiological responses of strawberry (Fragaria $\times$ ananassa) to exogenous salicylic acid application under drought stress. J. Agr. Sci. Tech., 17, 167-178.

Gomaa, E.F., Nassar, R.M.A. and Madkour, M.A. (2015) Effect of foliar spray with salicylic acid on vegetative growth, stem and leaf anatomy, photosynthetic pigments and productivity of egyptian lupine plant (Lupinus termis Forssk.). International Journal of Advanced Research, 3 (1), 803-813.

Hayat, S., Fariduddin,Q., Ali, B. and Ahmad, A. (2005) Effect of salicylic acid on growth and enzyme activities of wheat seedlings. Acta Agronomica Hungarica, 53 (4), 433-437. DOI: 10.1556/ AAgr.53.2005.4.9 
Hayat, S., Hasan, S.A., Hayat, Q., Irfan,M. and Ahmad, A. (2010) Effect of salicylic acid on net photosynthetic rate, chlorophyll fluorescence, and antioxidant enzymes in Vigna radiata plants exposed to temperature and salinity stresses. Plant Stress, $\mathbf{4}$, $62-71$.

Jain, A. and Srivastava, H.S. (1981) Effect of salicylic acid on nitrite reductase and glutamate dehydrogenase activities in maize roots. Physiologia Plantarum, 53 (3), 285-288. DOI: 10.1111/j.13993054.1981.tb04501.x

Jamali, B. and Eshghi, S. (2015) Salicylic acidinduced salinity redressal in hydroponically grown strawberry. Communications in Soil Science and Plant Analysis, 46 (12), 1482-1493. DOI: 10.1080/00103624.2015.1043447

Jamali, B., Eshghi, S. and Tafazoli, E. (2011) Vegetative and reproductive growth of strawberry plants cv. Pajaro affected salicylic acid and nickel. J. Agric. Sci. Tech., 13, 895-904.

Jamali, B., Eshghi, S. and Shahidi-Rad, K. (2015) Growth and fruit characteristics of strawberry cv. selva as affected by different application timing of salicylic acid under saline conditions. International Journal of Fruit Science, 15, 339-352. DOI: $10.1080 / 15538362.2015 .1015761$

Kalaki, G.S., Abdosi, V., Boojar, M.M.A. (2014) Change in chlorophylls composition and some morphological attributes of strawberry (Fragaria $\times$ ananassa Duch cv. Camarosa) in response to salicylic acid spray. International Journal of Biosciences, 5 (12), 2042011. DOI: $10.12692 / \mathrm{ijb} / 5.12 .204-211$

Karlidag, H., Yildirim, E. and Turan,M. (2009a) Exogenous application of salicylic acid affects quality and yield of strawberry grown under antifrost heated greenhouse condition. J. Plant Nutr. Soil Sci., 172, 270-276. DOI: 10.1002/jpln.200800058

Karlidag, H., Yildirim, E. and Turan, M. (2009b) Salicylic acid ameliorates the adverse effect of salt stress on strawberry. Sci. Agric. (Piracicaba, Braz.), 66 (2), $180-187$.

Kazemi, M. (2013) Foliar application of salicylic acid and calcium on yield, yield component and chemical properties of strawberry. Bull. Env. Pharmacol. Life Sci., 2 (11), 19-23.
Khan, W., Prithviraj, B. and Smith, D.L. (2003) Photosynthetic responses of corn and soybean to foliar application of salicylates. J. Plant Physiol., 160, 485-492.

Koller, H.R.C. (1972) Leaf area-leaf weight relationships in the soybean canopy. Crop Sci., 12 (2), 180-183. DOI: $10.2135 /$ cropsci1972.0011183 $\mathrm{X} 001200020007 \mathrm{x}$

Maas, J.L., Wang, S.Y. and Galletta, G.J. (1991) Evaluation of strawberry cultivars for allegic acid content. Hort Science, 26, 66-68.

Mady, M.A. (2014) Inducing cold tolerability in squash (Cucurbita pepo l.) plant by using salicylic acid and chelated calcium application. Int. J. Agric. Sci. Res., 4, 9- 24.

Metwally, A.A., Youssef,S.M., El-Miniawy, S.M. and Ragab, M.E. (2013) Effect of foliar spraying of salicylic acid on growth, yield and quality of cold stored strawberry plants. J. Biol. Chem. Environ. Sci., 8, 1-17.

Neufeld, H., Chappelka, A.H., Somers, G.L., Burkey, K.O., Davison, A.W. and Finkelstein, P. (2006) Visible foliar injury caused by ozone alters the relationship between SPAD meter readings and chlorophyll concentrations in cut leaf coneflower. Photosynth. Res., 87, 281-286.

Nour, K.A.M, Mansour,N.T.S. and Eisa, G.S.A. (2012) Effect of some antioxidants on some physiological and anatomical characters of snap bean plants. New York Science Journal, 5 (5), 1-9.

Piper, C.S. (1950) "Soil and Plant Analysis", $1^{\text {st }}$ ed, Interscience Publishers Inc., New York, USA, pp. $30-59$.

Qureshi, K.M., Chughtai,S., Qureshi, U.S. and Abbasi, N.A. (2013) Impact of exogenous application of salt and growth regulators on growth and yield of strawberry. Pak. J. Bot., 45 (4), 1179-1185.

Raskin, I. (1992) Role of salicylic acid in plants. Annu. Rev. Plant Physiol. Plant Mol. Biol., 43, 439-463.

Sairam, R.K., Deshmukh, P.S. and Shukla, D.S. (1997) Tolerance of drought and temperature stress in relation to increased antioxidant enzyme activity in wheat. J. Agron. Crop Sci., 178 (3), 171-178. DOI: 10.1111/j.1439-037X.1997.tb00486.x

Egypt. J. Hort. Vol. 44, No.1 (2017) 
Singh, P.K., Chaturvedi, V.K. and Bose, B. (2010) Effects of salicylic acid on seedling growth and nitrogen metabolism in cucumber (Cucumis sativus L.). Journal of Stress Physiology \& Biochemistry, 6 (3), 102-113.

Tohma, O. and Esitken, A. (2011) Response of salt stressed strawberry plants to foliar salicylic acid pre-treatments. Journal of Plant Nutrition, 34 (4), 590-599. DOI: 10.1080/01904167.2011.538285

Watanabe, F.S. and Olsen, S.R. (1965) Test of an ascorbic acid method for determining phosphorus in water and sodium bicarbonate extracts from soil. Soil Sci. Soc. Amer. Proc., 29, 677-678.
Yildirim, E., Turan, M. and Guvenc, I. (2008) Effect of foliar salicylic acid applications on growth, chlorophyll and mineral content of cucumber (Cucumis sativus L.) grown under salt stress. J. Plant Nutr., 31, 593-612. DOI: $10.1080 / 01904160801895118$

\title{
تكرار مرات الرش بحمض الساليسيليك بثركيزات مرتفعة تحسن النمو والمحصول وجودة الثمار لنباتات صنف الفراولة فيستيفال \\ صبري موسى سليمان يوسف، نشوه عطية إبراهيم أبو العزم و سلامه عبد الحميا عبد الهادي

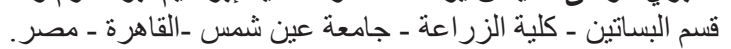

\begin{abstract}
حمض الساليسيليك ينظم العديد من العمليات الفسيولوجية و البيوكيمائية فى النبات. الدر اسات السابقة على الفر اولة

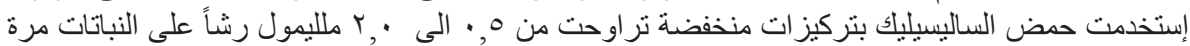

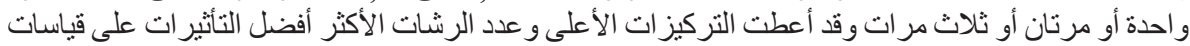

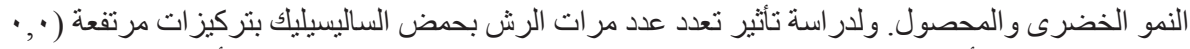

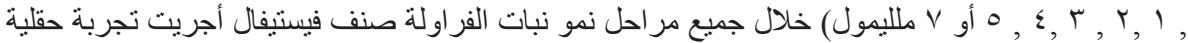

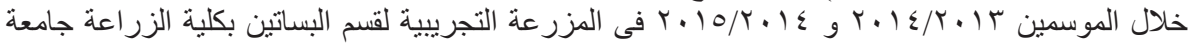

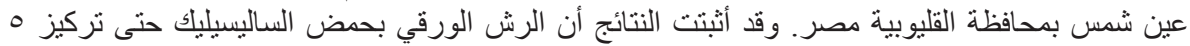

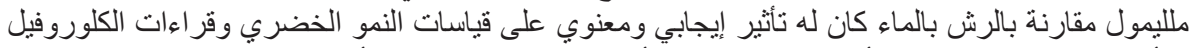

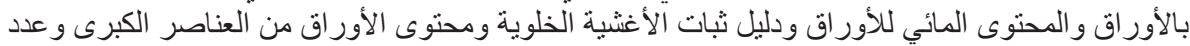

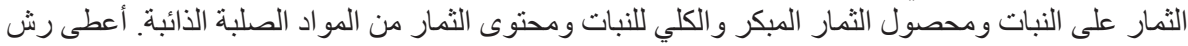

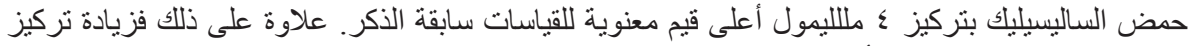

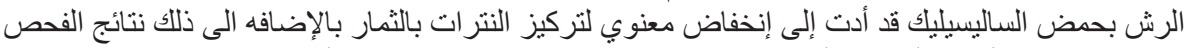

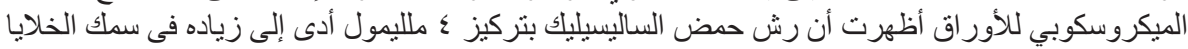

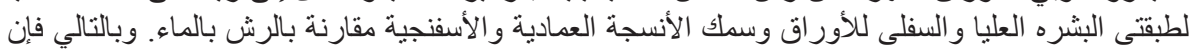
الرش بحمض سالبسيليك بتركيز ؟ ملليمول يمكن أن توفر وسيلة اقتصادية وسريعة وقابلة للتطبيق وفعالة لتحسين النمو و المحصول وجودة الثمار لصنف الفر اولة فيستيفال.
\end{abstract}

